\title{
PENGARUH PENDEKATAN PEMBELAJARAN KOOPERATIF DAN SEL $F$ MONITORING SISWA TERHADAP KEMAMPUAN BERPIKIR ILMIAH DALAM BIOLOGI BAGI SISWA KELAS X SMA
}

\author{
Gusti Nurdin \\ Universitas Terbuka \\ e-mail: gnur@ut.ac.id
}

\begin{abstract}
The purpose of this study was to describe (1) the ability to follow the scientific thinking of students learning with cooperative learning. (2) differences in scientific thinking skills among students who have self-monitoring high and students who have self-monitoring low (3) differences in scientific thinking skills of students who have self-monitoring high following study with cooperative learning learning students (4) differences in scientific thinking skills of students who have low self-monitoring which follows cooperative learning students in the subjects of biology in high school. (5) the effect of the interaction between learning strategy and self-monitoring of the scientific thinking skills. The research location is housed in SMA 22 Jakarta Timur. With descriptive results, the low self-monitoring group, the average student learning outcomes before treatment amounted to 58,55. After scientific thinking and treatment, an increase in the average learning result of 72,91 and 84,18. Likewise, the high self-monitoring group, the average student learning outcomes before treatment was of 58,33. After scientific thinking and treatment, an increase in the average learning result of 71,17 and 81,33 . The average value of student learning outcomes before treatment amounted 58,43. Setelah scientific thinking and treatment, the average student learning outcomes increased by 72,0 and 82,70 . The average value of student learning outcomes before treatment amounted 58,43. Setelah scientific thinking and treatment, be increased by 72,0 and 82,70 . The average value of student learning outcomes low self-monitoring group amounted to 71,88 . The average results of students 'self-monitoring group high of 70,28 . Sebelum treatment, the average value of the students' self-monitoring group a low of 58,55 . The average results of students' self-monitoring group high of 58,33. The difference in value of student learning outcomes between low self-monitoring groups did not differ significantly with high self-monitoring after treatment.
\end{abstract}

Keywords: cooperative learning, scientific thinking, self-monitoring.

\begin{abstract}
ABSTRAK
Tujuan penelitian ini adalah mendeskripsikan (1) kemampuan berpikir ilmiah siswa yang mengikuti pembelajaran dengan pembelajaran kooperatif. (2) perbedaan kemampuan berpikir ilmiah antara siswa yang memiliki self monitoring tinggi dan siswa yang memiliki self monitoring rendah (3) perbedaan kemampuan berpikir ilmiah siswa yang memiliki self monitoring tinggi yang mengikuti pembelajaran dengan pembelajaran kooperatif learning siswa (4) perbedaan kemampuan berpikir ilmiah siswa yang memiliki self monitoring rendah yang mengikuti pembelajaran kooperatif siswa dalam mata pelajaran biologi di SMA. (5) pengaruh interaksi antara strategi pembelajaran dengan self monitoring terhadap
\end{abstract}


kemampuan berpikir ilmiah. Lokasi penelitian ini bertempat di SMA 22 Jakarta Timur. Dengan hasil secara deskriptif, pada kelompok self monitoring rendah, rata-rata hasil belajar siswa sebelum treatment adalah sebesar 58,55. Setelah berpikir ilmiah dan treatment, terjadi peningkatan rata-rata hasil belajar sebesar 72,91 dan 84,18. Demikian juga pada kelompok self monitoring tinggi, rata-rata hasil belajar siswa sebelum treatment adalah sebesar 58,33 . Setelah berpikir ilmiah dan treatment, terjadi peningkatan rata-rata hasil belajar sebesar 71,17 dan 81,33. Rata-rata nilai hasil belajar siswa sebelum treatment adalah sebesar 58,43.Setelah berpikir ilmiah dan treatment, rata-rata hasil belajar siswa meningkat sebesar 72,0 dan 82,70. Rata-rata nilai hasil belajar siswa sebelum treatment adalah sebesar 58,43 .Setelah berpikir ilmiah dan treatment, menjadi meningkat sebesar 72,0 dan 82,70 . Rata-rata nilai hasil belajar siswa kelompok self monitoring rendah adalah sebesar 71,88 . Rata-rata hasil belajar siswa kelompok self monitoring tinggi sebesar 70,28 .Sebelum treatment, rata-rata nilai hasil belajar siswa kelompok self monitoring rendah sebesar 58,55. Rata-rata hasil belajar siswa kelompok self monitoring tinggi sebesar 58,33 . Selisih nilai hasil belajar siswa antara kelompok self monitoring rendah tidak berbeda signifikan dengan self monitoring tinggi setelah treatment.

Kata kunci: berpikir ilmiah, pembelajaran kooperatif, self monitoring.

Guru dalam melakukan kegiatan pembelajaran di sekolah untuk keberhasilannya dalam pembelajaran menggunakan strategi, dan salah satu strategi pembelajaran yang bisa diterapkan dalam proses mengajar di sekolah adalah strategi pembelajaran kooperatif, selanjutnya dalam penelitian ini untuk strategi pembelajaran menggunakan strategi pembelajaran kooperatif.

Pada saat strategi pembelajaran kooperatif dilaksanakan maka kegiatan pembelajarannya berlangsung dengan suatu pembelajaran secara kelompok dengan jumlah peserta didik dua sampai lima orang dengan gagasan untuk saling memotivasi antara anggotanya untuk saling membantu agar tercapainya suatu tujuan pembelajaran yang maksimal. Depdiknas (2003:5). "Pembelajaran Kooperatif (cooperative learning) merupakan strategi pembelajaran melalui kelompok kecil siswa yang saling bekerja sama dalam memaksimalkan kondisi belajar untuk mencapai tujuan belajar". Slavin (Isjoni, 2011:15). "In cooperative learning methods, students work together in four member teams to master material initially presented by the teacher". Ini berarti bahwa cooperative learning atau pembelajaran kooperatif adalah suatu model pembelajaran dimana sistem belajar dan bekerja kelompok-kelompok kecil berjumlah antara empat sampai enam orang secara kolaboratif sehingga dapat merangsang peserta didik lebih bergairah dalam belajar. Dari beberapa pengertian menurut uraian demikian dapat disimpulkan bahwa "pembelajaran kooperatif adalah cara belajar dalam bentuk kelompok-kelompok kecil yang saling bekerjasama dan diarahkan oleh guru untuk mencapai tujuan pembelajaran yang diharapkan".

Berpikir secara ilmiah merupakan proses penerapan teknik ilmiah untuk meneliti fenomena, mendapatkan ilmu pengetahuan baru yang diintegrasikan dengan ilmu pengehuan sebelumnya atau mengoreksi pengetahuan sebelumnya. Selain itu juga merupakan pendekatan berpikir sistematis dalam menghimpun data dalam menyelesaikan masalah. Membangun hubungan sebab akibat pada sistem yang melibatkan satu atau beberapa variable, dan cara berpikir mengenai subjek ilmiah, isi, atau masalah sehingga seseorang dapat meningkatkan kualitas keterampilan berpikirnya serta merefleksikan struktur yang melekat dalam pikirannya serta mematuhi standar intelektualnya. Self- 
monitoring adalah kecenderungan untuk merubah perilaku dalam merespon terhadap presentasi diri yang dipusatkan pada situasi pembelajaran biologi (Brehm \& Kassin, 1993). Atau menurut Worchel, dkk. (2000), self-monitoring adalah menyesuaikan perilaku terhadap norma-norma situasional dan harapan-harapan dari orang lain. Sementara (Brigham, 1991) menyatakan self-monitoring merupakan proses dimana individu mengadakan pemantauan atau memonitor terhadap pengelolaan kesan yang telah dilakukannya.

Penelitian ini membatasi diri pada salah satu faktor eksternal saja yang meliputi guru, materi pelajaran, strategi pembelajaran yang digunakan oleh guru, sistem penilaian, sarana fisik, keluarga, dan masyarakat sebagai variabel bebas, dalam faktor eksternal "strategi pembelajaran" dan faktor "self monitoring" siswa. Diduga kedua faktor tersebut mempengaruhi kemampuan dalam biologi siswa kelas X di Sekolah Menengah Atas. Juga membatasi diri pada self monitoring tinggi dan self monitoring rendah.Selanjutnya, variabel kemampuan menyelesaikan soal-soal biologi. Hasil belajar yang akan diambil sebagai data penelitian ini dibatasi pada hasil belajar yang berkaitan dengan materi pembelajaran yang disajikan pada siswa SMA kelas X, semester I. Sehingga masalah pokok dalam penelitian ini adalah "Apakah ada pengaruh pembelajaran kooperatif dan self monitoring terhadap kemampuan berpikir ilmiah dalam biologi siswa kelas X SMA ?"

Tujuan pembelajaran akan dapat dicapai dengan memperhatikan faktor-faktor internal dan eksternal siswa. Dalam penelitian ini menempatkan strategi pembelajaran sebagai variabel bebas (independent variable) dan self monitoring sebagai variabel atribut. Selanjutnya kemampuan menyelesaikan soal-soal Biologi sebagai variabel terikat (dependent variable). Selain itu tujuan penelitian ini adalah untuk mendeskripsikan kemampuan berpikir ilmiah siswa yang mengikuti pembelajaran dengan pembelajaran kooperatif dalam mata pelajaran biologi di Sekolah Menengah Atas? Mendeskripsikan perbedaan kemampuan berpikir ilmiah antara siswa yang memiliki self monitoring tinggi dan siswa yang memiliki self monitoring rendah dalam mata pelajaran biologi di Sekolah Menengah Atas? Mendeskripsikan perbedaan kemampuan berpikir ilmiah siswa yang memiliki self monitoring tinggi yang mengikuti pembelajaran dengan pembelajaran kooperatif learning siswa dalam mata pelajaran biologi di Sekolah Menengah Atas? Mendeskripsikan perbedaan kemampuan berpikir ilmiah siswa yang memiliki self monitoring rendah yang mengikuti pembelajaran kooperatif siswa dalam mata pelajaran biologi di Sekolah Menengah Atas? Mendeskripsikan pengaruh interaksi antara strategi pembelajaran dengan self monitoring terhadap kemampuan berpikir ilmiah dalam mata pelajaran biologi di Sekolah Menengah Atas?

\section{METODE PENELITIAN}

Lokasi penelitian ini bertempat di SMA 22 Jakarta Timur,dengan pelaksanaanlebih kurang selama duabulan. Satu bulan pertama, digunakan untuk uji coba instrumen dan pengolahan data agar diketahui tingkat validitas dan reliabilitas instrumen penelitian. Satu bulan berikutnya, pengambilan data di lapangan, dan analisis data.

Instrumen pengukur hasil belajar Biologi kelas X SMA yang telah disusun, sebelum digunakan pada subjek penelitian, terlebih dahulu dilakukan kalibrasi melalui kegiatan uji coba (try out) pada siswa yang bukan subjek penelitian.

Validitas butir merupakan salah satu indikator penentu kualitas tes. Suatu tes dikatakan valid apabila tes tersebut dapat mengukur apa yang seharusnya diukur. Pengujian validitas dilakukan dengan menguji validitas internal atau validitas butir yang diperoleh dari korelasi antara skor butir dengan skor total. Jadi validitas butir merupakan indeks koefisien korelasi antara skor butir dengan skor total. Pada dasarnya indeks tersebut menunjukkan apakah variasi skor butir konsisten dengan 
variasi skor total. Indeks koefisien korelasi juga sebagai petunjuk tentang kemampuan butir yang bersangkutan membedakan kemampuan responden. Oleh karena itu, validitas butir seringkali disebut daya beda. Semakin tinggi nilai koefisien korelasi, semakin tinggi kemampuan daya bedanya, demikian sebaliknya. Skor pada tes hasil belajar biologi adalah dikotomi, maka teknik analisis yang digunakan adalah korelasi point biserial $\left(r_{p b i s}\right)$ dengan rumus:

Keterangan:

$$
r_{p b i s}=\frac{\left(\bar{x}_{i}-\bar{x}_{t}\right)}{S} \sqrt{\frac{p}{q}}
$$

$r_{p b i s}:$ Korelasi point biserial

$\bar{x}_{i} \quad$ : Rata-rata skor untuk yang menjawab benar

$\bar{x}_{t} \quad$ : Rata-rata skor total

p : Proporsi yang menjawab benar pada butir (tingkat kesulitan)

$\mathrm{q} \quad$ : Proporsi yang menjawab salah pada butir $=1-\mathrm{p}$

S : Simpangan baku skor total

Reliabilitas tes adalah salah satu indikator penentu kualitas tes. Suatu tes dikatakan reliabel apabila hasil-hasil pengukuran yang dilakukan dengan tes tersebut secara berulang kali terhadap subjek yang sama menunjukkan hasil yang tetap, "ajeg" dan stabil ntuk menguji reliabilitas tes hasil belajar biologi, peneliti menggunakan teknik analisis Kuder-Richardson 20 (KR-20) dengan rumus:

$$
r_{t t}=\frac{k}{k-1}\left(1-\frac{\sum p q}{S_{t}^{2}}\right)
$$

dengan:

$r_{\mathrm{tt}} \quad$ : Koefisien reliabilitas

$\mathrm{k} \quad$ : Jumlah item yang valid

$S_{t}^{2} \quad$ : Varian total.

Pemanfatan self monitoring dalam penelitian ini menggunakan angket yang diberikan kepada siswa sebelum pembelajaran biologi berlangsung. Sedang untuk langkah-langkah berpikir ilmiah diterapkan oleh guru saat pembelajaran biologi di kelas X SMA Negeri 22 sebagai metode atau pendekatan. Mulai dari mengobservasi, membandingkan, mengelompokan, memprediksi, bereksperimen, mengevaluasi, dan menerapkan. Untuk pembelajaran kooperatif learning digunakan bersamaan dengan pendekatan berpikir ilmiah.

\section{HASIL ANALISIS}

Untuk mengetahui pengaruh self monitoring dan pemberian perlakuan terhadap hasil belajar siswa merupakan bagian dari penelitian ini dengan memilih 37 orang siswa untuk dijadikan sampel. Setelah itu dikelompokkan berdasarkan skor self monitoring, siswa tersebut diurutkan dari skor terendah ke skor tertinggi. Siswa yang sudah diurutkan dari skor terendah ke skor tertinggi selanjutnya diambil $27 \%$ siswa dengan urutan terendah untuk mewakili siswa yang memiliki self monitoringrendah, dan $27 \%$ siswa dengan urutan tertinggi untuk mewakili siswa yang memiliki self monitoring tinggi. Berdasarkan hasil pengelompokan self monitoring, didapatkan jumlah siswa dan pengelompokan dipaparkan pada Tabel 1. 
Tabel 1. Self Monitoring Siswa

\begin{tabular}{cc}
\hline Self Monitoring & Jumlah Siswa \\
\hline Rendah & 11 \\
Tinggi & 12 \\
\hline
\end{tabular}

Berdasarkan pada Tabel 1 ditunjukkan bahwa dari 37 siswa yang diteliti, 11 siswa termasuk dalam kategori self monitoring rendah dan 12 siswa termasuk dalam kategori tinggi. Sehingga jumlah siswa yang digunakan dalam analisis selanjutnya adalah sebanyak 23 siswa. Secara deskriptif, ratarata hasil belajar siswa sebelum dan sesudah berpikir ilmiah pada masing-masing kelompok self monitoring adalah seperti terlihat pada Tabel 2.

Tabel 2. Self Monitoring Siswa Setelah Treatment

\begin{tabular}{lccc}
\hline \multirow{2}{*}{ Self Monitoring } & \multicolumn{3}{c}{ Rata-Rata Hasil Belajar } \\
\cline { 2 - 4 } & Sebelum treatment & Berpikir ilmiah & Setelah Treatment \\
\hline Rendah & 58,55 & 72,91 & 84,18 \\
Tinggi & 58,33 & 71,17 & 81,33 \\
\hline
\end{tabular}

Secara deskriptif, didapatkan bahwa pada kelompok self monitoring rendah, rata-rata hasil belajar siswa sebelum treatment adalah sebesar 58,55 . Setelah berpikir ilmiah dan treatment, terjadi peningkatan rata-rata hasil belajar sebesar 72,91 dan 84,18 . Demikian juga pada kelompok self monitoring tinggi, rata-rata hasil belajar siswa sebelum treatment adalah sebesar 58,33 . Setelah berpikir ilmiah dan treatment, terjadi peningkatan rata-rata hasil belajar sebesar 71,17 dan 81,33. Berdasarkan pada tabel tersebut, ditunjukkan bahwa pada semua kelompok self monitoring terjadi peningkatan hasil belajar setelah berpikir ilmiah dan treatment.

Untuk mengetahui perbedaan peningkatan hasil belajar siswa antara kelompok self monitoring rendah dengan self monitoring tinggi sebelum dan sesudah berpikir ilmiah dan treatment, dilakukan proses analisis dengan menggunakan Two Way ANOVA. Namun sebelum dianalisis lebih lanjut, terlebih dahulu dilakukan pengujian asumsi yang melandasi ANOVA.

Terdapat dua asumsi yang melandasi ANOVA, yakni asumsi normalitas dan homogenitas ragam. Pengujian asumsi normalitas dilakukan dengan menggunakan uji Kolmogorov-Smirnov. Asumsi normalitas dikatakan terpenuhi jika $p$-value hasil penghitungan lebih besar dari $\alpha=0,05$. Dengan menggunakan bantuan software SPSS didapatkan hasil pengujian asumsi normalitas yang dipaparkan pada Tabel 3.

Tabel 3. Hasil Uji Normalitas

\begin{tabular}{cccc}
\hline & Koefisien & $p$-value & Keterangan \\
\hline Hasil Belajar & 0,862 & 0,448 & Normal \\
\hline
\end{tabular}

Berdasarkan pada Tabel 3 , didapatkan $p$-value lebih besar daripada $a=0,05(p>0,05)$. Sehingga, dari pengujian ini dapat disimpulkan bahwa asumsi normalitas telah terpenuhi.Pengujian asumsi homogenitas ragam dilakukan dengan menggunakan uji Levene. Asumsi homogenitas ragam dikatakan terpenuhi jika $p$-value hasil penghitungan lebih besar daripada $a=0,05$. Berikut hasil pengujian asumsi homogenitas ragam dengan menggunakan bantuan software SPSS dipaparkan pada Tabel 4. 
Tabel 4. Hasil Uji Homogenitas

\begin{tabular}{cccc}
\hline Variabel & Koefisien & $p$-value & Keterangan \\
\hline Hasil Belajar & 1,919 & 0,104 & Homogen \\
\hline
\end{tabular}

Berdasarkan Tabel 4, didapatkan $p$-value lebih besar daripada $\alpha=0,05(p>0,05)$. Sehingga dari pengujian ini dapat disimpulkan bahwa asumsi homogenitas ragam telah terpenuhi. Hasil analisis dengan menggunakan ANOVA disajikan dalam Tabel 5.

Tabel 5. Hasil Analisis Asumsi untuk Pembelajaran Kooperatif dan Self Monitoring terhadap Kemampuan Berfikir Ilmiah

\begin{tabular}{cccrrr}
\hline Sumber Keragaman & Jumlah Kuadrat & df & Kuadrat Tengah & F-hitung & $p$-value \\
\hline Pembelajaran Kooperatif & 6.819 .653 & 2 & 3.409 .827 & 564.908 & $0,000^{\text {** }}$ \\
Self Monitoring & 44.132 & 1 & 44.132 & 7.311 & $0,009^{* *}$ \\
Interaksi & 20.117 & 2 & 10.058 & 1.666 & $0,197^{\text {ns }}$ \\
Error & 380.273 & 63 & 6.036 & & \\
\hline Total & 7244.875 & 68 & & & \\
\hline
\end{tabular}

Berdasarkan hasil ANOVA pada Tabel 5 , pada sumber keragaman Perlakuan didapatkan $p$ value sebesar $0,000(p<0,05)$. Hal ini menunjukkan bahwa pemberian perlakuan pada siswa mampu meningkatkan skor hasil belajar siswa. Atau dengan kata lain, terdapat perbedaan yang signifikan rata-rata hasil belajar siswa sebelum treatment dengan setelah berpikir ilmiah dan treatment. Berikut perbandingan rata-rata hasil belajar siswa sebelum dan sesudah berpikir ilmiah dipaparkan pada Tabel 6 .

Tabel 6. Perbandingan Hasil Treatment

\begin{tabular}{cc}
\hline Perlakuan & Rata-Rata Hasil Belajar \\
\hline Sebelum treatment & 58,43 \\
Setelah berpikir kritis & 72,00 \\
Setelah Treatment & 82,70 \\
\hline
\end{tabular}

Berdasarkan pada Tabel 6, diketahui bahwa rata-rata nilai hasil belajar siswa sebelum treatment adalah sebesar 58,43.Setelah berpikir ilmiah dan treatment, rata-rata hasil belajar siswa meningkat sebesar 72,0 dan 82,70. Rata-rata peningkatan hasil belajar siswa seperti pada Grafik 1.

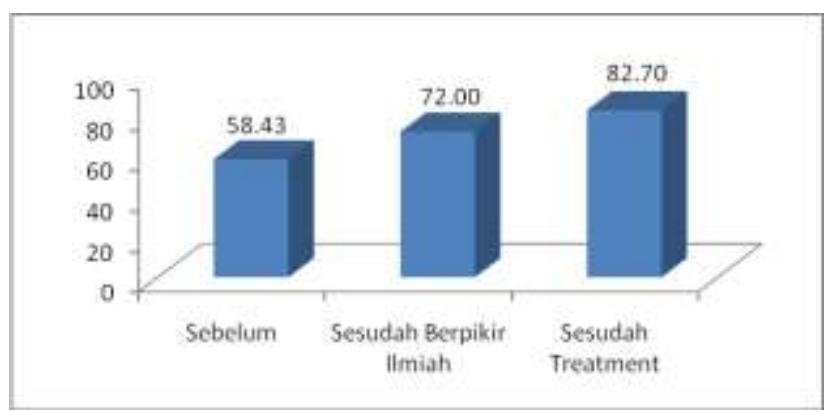

Grafik 1. Peningkatan hasil belajar siswa 
Berdasarkan hasil ANOVA, pada sumber keragaman Self Monitoring didapatkan $p$-value sebesar 0,009 $(p<0,05)$. Hal ini menunjukkan bahwa jenis self monitoring siswa memberikan pengaruh terhadap nilai hasil belajar siswa. Atau dengan kata lain, terdapat perbedaan yang signifikan rata-rata hasil belajar siswa antara kelompok self monitoring rendah dengan self monitoring tinggi. Berikut perbandingan rata-rata hasil belajar siswa self monitoring rendah dengan self monitoring tinggi.

Tabel 7. Perbandingan Self Monitoring Siswa

\begin{tabular}{cc}
\hline Self Monitoring & Rata-Rata Hasil Belajar \\
\hline Rendah & 71,88 \\
Tinggi & 70,28 \\
\hline
\end{tabular}

Berdasarkan pada Tabel 7, diketahui bahwa rata-rata nilai hasil belajar siswa kelompok self monitoring rendah adalah sebesar 71,88. Sedangkan rata-rata hasil belajar siswa kelompok self monitoring tinggi sebesar 70,28 . Hal ini menunjukkan bahwa rata-rata hasil siswa kelompok kelompok self monitoring rendah lebih tinggi daripada kelompok self monitoring tinggi. Grafik 2 merupakan perbandingan rata-rata hasil belajar siswa kedua kelompok tersebut.

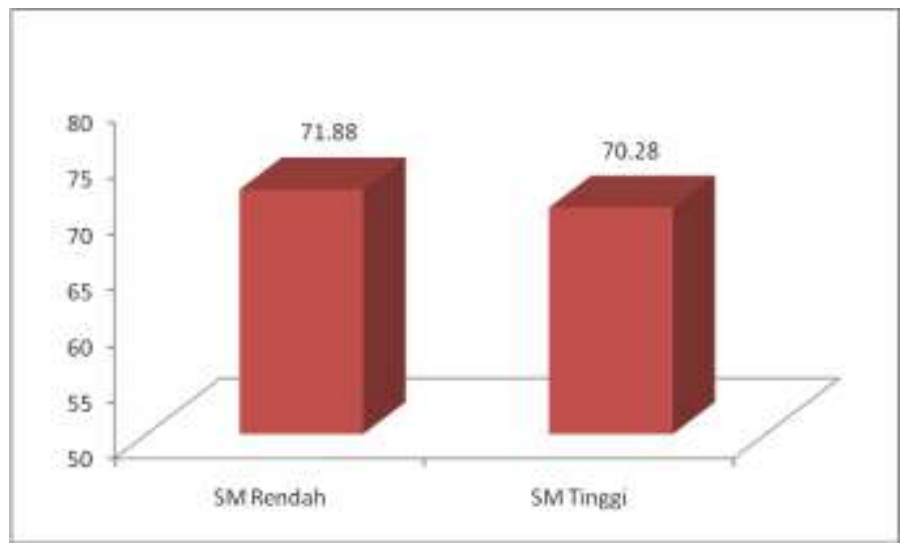

Grafik 2. Perbandingan hasil belajar siswa

Berdasarkan hasil ANOVA, pada sumber keragaman Interaksi didapatkan p-value sebesar 0,197 ( $p>0,05$ ). Hal ini menunjukkan bahwa faktor interaksi tidak memberikan pengaruh yang signifikan terhadap nilai hasil belajar siswa. Atau dengan kata lain, tidak terdapat perbedaan yang signifikan rata-rata hasil belajar siswa pada faktor interaksi. Berikut rata-rata hasil belajar siswa berdasarkan pada faktor interaksi dipaparkan pada Tabel 8.

Berdasarkan pada Tabel 8 , sebelum treatment, diketahui bahwa rata-rata nilai hasil belajar siswa kelompok self monitoring rendah adalah sebesar 58,55 . Sedangkan rata-rata hasil belajar siswa kelompok self monitoring tinggi sebesar 58,33 . Selisih nilai hasil belajar siswa antara kelompok self monitoring rendah tidak berbeda signifikan dengan self monitoring tinggi pada sebelum treatment. Setelah berpikir ilmiah, rata-rata nilai hasil belajar siswa kelompok self monitoring rendah adalah sebesar 72,91 . 
Tabel 8. Hasil Belajar Siswa Berdasarkan Faktor Interaksi

\begin{tabular}{ccc}
\hline Perlakuan & Self Monitoring & Rata-Rata Hasil Belajar \\
\hline Sebelum Treatment & Self Monitoring Rendah & 58,55 \\
& Self Monitoring Tinggi & 58,33 \\
Setelah Berpikir ilmiah & Self Monitoring Rendah & 72,91 \\
& Self Monitoring Tinggi & 71,17 \\
Setelah Treatment & Self Monitoring Rendah & 84,18 \\
& Self Monitoring Tinggi & 81,33 \\
\hline
\end{tabular}

Sedangkan rata-rata hasil belajar siswa kelompok self monitoring tinggi sebesar 71,17. Selisih nilai hasil belajar siswa antara kelompok self monitoring rendah tidak berbeda signifikan dengan self monitoring tinggi setelah berpikir ilmiah.

Setelah treatment, rata-rata nilai hasil belajar siswa kelompok self monitoring rendah adalah sebesar 84,18 . Sedangkan rata-rata hasil belajar siswa kelompok self monitoring tinggi sebesar 81,33 . Selisih nilai hasil belajar siswa antara kelompok self monitoring rendah tidak berbeda signifikan dengan self monitoring tinggi setelah treatment. Grafik 3 merupakan rata-rata hasil belajar siswa masing-masing kelompok.

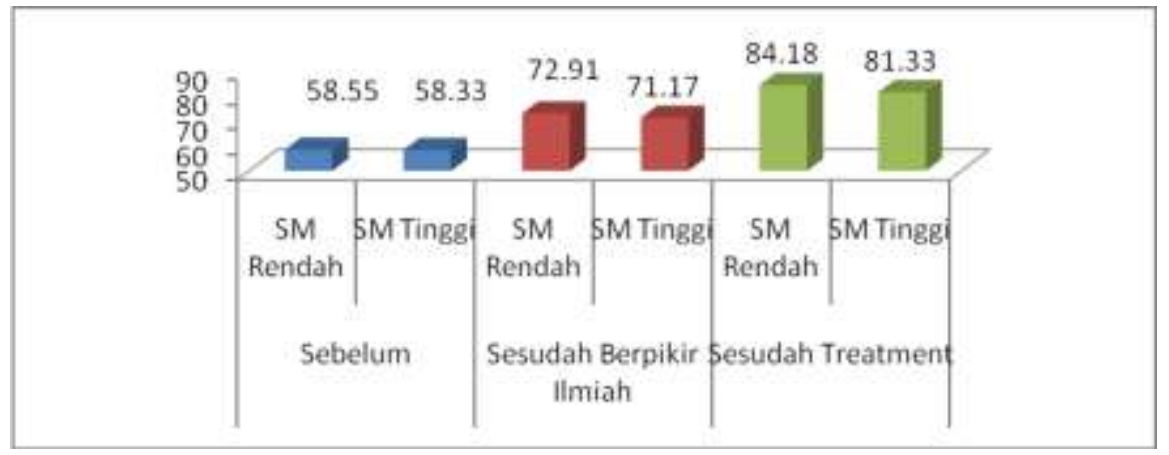

Grafik 3. Hasil Belajar Kelompok

Berdasarkan pada gambar Grafik 3, dapat dijelaskan bahwa peningkatan rata-rata hasil belajar siswa setelah berpikir ilmiah dan treatment antara kelompok self monitoring rendah dengan self monitoring tinggi relatif sama. Atau dengan kata lain, berpikir ilmiah dan tretment memberikan pengaruh yang relatif sama pada kedua kelompok tersebut, tidak terdapat kecenderungan bahwa berpikir ilmiah dan treatment lebih sesuai jika diberikan pada salah satu kelompok self monitoring. Sehingga berpikir ilmiah dan treatment pada kedua kelompok self monitoring mampu meningkatkan hasil belajar siswa dengan efek yang sama.

\section{PEMBAHASAN}

Berpikir ilmiah merupakan berpikir sistematis, dimulai dari merumuskan masalah yang diikuti dengan merumuskan hipotesis. Menghimpun data dan menyelesaikan masalah. Berpikir ilmiah merupakan metode eksperimental untuk membantu mengkonfirmasi atau meniadakan hipotesis. Data dikumpulkan melalui percobaan yang diamati, data diolah, lalu disimpulkan. Siswa yang dilatih 
untuk berpikir, pada awalnya merasa mengalami kesulitan, karena belum terbiasa siswa masih banyak melakukan kesalahan saat melakukan diskusi. Namun setelah diberi pengarahan dan bimbingan siswa mulai dapat merumuskan masalah dari sekian banyak yang dihadapinya. Setelah paham tentang merumuskan masalah siswa dapat membuat hipotesis dan mulai dapat mengumpulkan data yang diperlukan.

Berpikir secara ilmiah merupakan proses penerapan teknik ilmiah untuk meneliti fenomena, mendapatkan ilmu pengetahuan baru yang diintegrasikan dengan ilmu pengetahuan sebelumnya dapat membangun hubungan sebab akibat pada sistem yang melibatkan satu atau beberapa sistem dari materi pelajaran biologi yang diberikan guru. Siswa sudah mulai dapat mengidentifikasi materi biologi mulai dari tingkat kesukarannya yaitu dengan memilah-milah materi hingga menjadi beberapa bagian.

Berpikir ilmiah merupakan cara berpikir mengenai subjek ilmiah, isi, atau masalah sehingga siswa telah dapat meningkatkan kualitas keterampilan berpikirnya serta merefleksikan struktur yang melekat dalam pikirannya serta mematuhi standar intelektual. Sesuai dengan pendapat itu maka penerapan berpikir ilmiah menurut Antonio Zamora (2000) terdiri atas empat tahap yakni: Melakukan observasi dan mendeskripsikan gejala alam atau fenomena, observsi dapat dilakukan secara visual atau dengan bantuan teknologi. Merumuskan hipotesis untuk menjelaskan fenomena dalam hubungan sebab akibat atau dalam hubungan matematis. Menguji hipotesis dengan menganalisis hasil observasi atau dengan prediksi dan hasil observasi tentang adanya fenomena baru, jika percobaan tidak dapat membuktikan kebenaran hipotesis maka hipotesis harus ditolak atau diubah, dan kegiatan kembali ke merumuskan hipotensi. Menetapkan teori melalui verifikasi ulang.

Empat kegiatan ilmiah tersebut di atas dideskripsikan dalam diagram sebagai berikut.

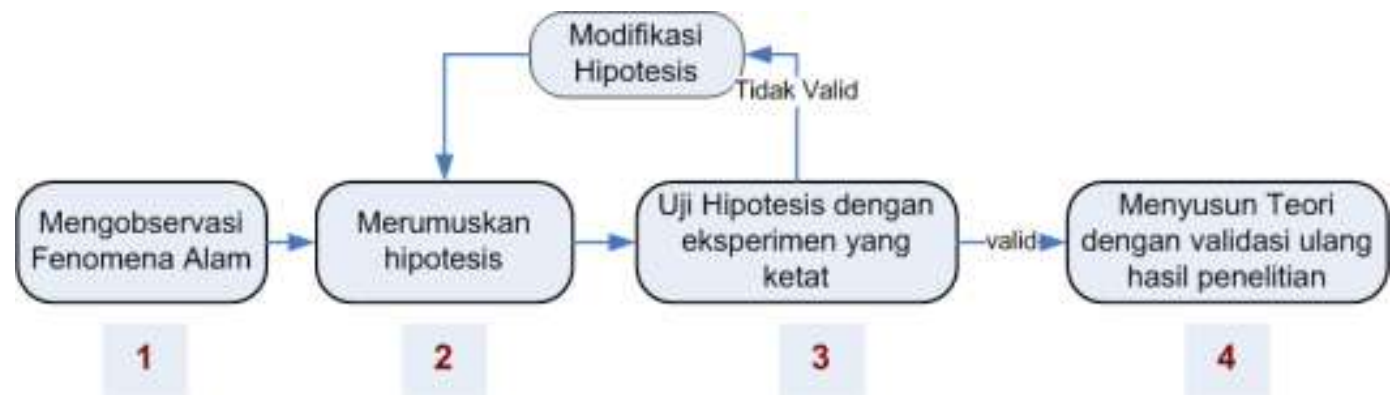

Untuk menerapkan konsep tersebut, ada banyak hal yang perlu siswa perhatikan agar konsistem dalam menerapkan metode berpikir ilmiah. Di antaranya adalah mengembangkan pertanyaan atau masalah, merumuskan masalah dengan jelas dan tepat; mengumpulkan dan menilai data yang ilmiah serta relevan atau informasi, menggunakan ide-ide abstrak untuk menafsirkan data secara efektif dan; Mengembangkan dasar yang kuat untuk memeperoleh kesimpulan dan solusi yang ilmiah, mengujinya dengan menggunakan kriteria dan standar yang relevan serta; Berpikir konvergen dengan menerapkan sistem pemikiran ilmiah, mengakui dan menilai asumsi ilmiah, implikasi, dan konsekuensi praktis. Pemikiran konvergen mengarah pada jawaban tertentu atau terpusat pada sasaran akhir. (sedangkan lawannya, pemikiran divergen merupakan cara berpikir mengeksplorasi dan kreativitif, terbuka dan bergerak menjauh) terakhir; Berkomuniksi secara efektif dengan berbagai orang untuk mengembangkan solusi terbaik dalam memecahkan masalah yang kompleks. 
Kaidah-kaidah di atas sebagai pondasi untuk mengembangkan keterampilan siswa berpikir ilmiah melalui beberapa contoh indikator kompetensi dikemukakan oleh Mosby's (2009), sebagai berikut. Yaknimerumuskan masalah dengan mangajukan pertanyaan mengenai objek tertentu yang jelas batas-batasnya. Menyusun kerangka berpikir dengan mengajukan hipotesis atau pertanyaan yang menjelaskan adanya hubungan yang mungkin antara faktor yang berkaitan sehingga menimbulkan masalah. Merumuskan hipoteis sebagai kesimpulan dan jawaban sementara atas pertanyaan atau permasalahan yang dijadikan sebagai kerangka pikiran. Menguji hipotesis dengan cara mengumpulkan fakta yang relevan dengan hipotensis yang diajukan. Data digunakan untuk membuktikan ada atau tidak adanya yang mendukung hipotesis. Menafsirkan data yang diperolehnya sehingga bermakna. Menarik kesimpulan; menilai apakah hipotesis yang diajukan itu ditolak atau diterima. Mengkomunikasikan hasil studinya dalam bentuk laporan penelitian. Mengkomunikasikan hasil studinya dalam presentasi di kelas. Mempertahankan kesimpulan yang telah disusunnya dengan menggunakan argumentasi yang berlandaskan data. Menyajikan hasil studinya dalam forum ilmiah.Dan terakhir menyajikan hasil studinya dalam web sekolah.

Dalam mengembangkan keterampilan berpikir sebaiknya siswa terlatih sejak dini dengan cara mengasah keterampilan berpikir ilmiahnya. Melalui pengembangan keterampilan ini siswa dapat mengembangkan rasa ingin tahu. Untuk mengembangkan kompetensi ini guru dapat memicu siswa dengan menggunakan indikator belajar seperti di bawah ini. Menurut Church (2006) mengungkapkan alasan 'mengapa hal itu menjadi bahan pemikirannya?' Memicu siswa dengan melakukan langkahlangkah sebagai berikut yakni: Mengajukan pertanyaan. Memprediksi dengan cara menceritakan apa yang mungkin terjadi. Melihat, memperhatikan, mendengarkan, menyentuh, mencium, dan mencicipi sehingga mendapatkan informasi yang akurat mengenai suatu hal. Mengelola informasi dengan cara berbicara atau menuliskan tentang hal yang menjadi bahan perhatian. Membandingkan tentang bagaimana hal itu bisa sama. Membandingkan tentang bagaimana hal itu bisa berbeda.

Menggunakan kata-kata untuk menggambarkan terjadinya sesuatu. Menguraikan hasil penelitian dengan menggunakan diagram. Menggambarkan sesuatu dengan menggunakan data berupa foto. Membuktikan sesuatu dengan data berbentuk table. Memperlihatkan kondisi hasil pembelajaran dengan menggunakan grafik. Menggambarkan kondisi hasil pembelajaran dengan menggunakan data dalam bentu angka. Menafsirkan data sehingga bermakna. Menarik kesimpulan mengenai hal yang pelajarinya.

Berfikir merupakan ciri utama bagi manusia. Berfikir disebut juga sebagai proses bekerjanya akal. Secara garis besar berfikir dapat dibedakan antara berfikir alamiah dan berfikir ilmiah. Berfikir alamiah adalah pola penalaran yang berdasarkan kehidupan sehari-hari dari pengaruh alam sekelilingnya. Berfikir ilmiah adalah pola penalaran berdasarkan sarana tertentu secara teratur dan cermat.

Bagi seorang ilmuan penguasaan sarana berfikir ilmiah merupakan suatu keharusan, karena tanpa adanya penguasaan sarana ilmiah, maka tidak akan dapat melaksanakan kegiatan ilmiah dengan baik. Sarana ilmiah pada dasarnya merupakan alat untuk membantu kegiatan ilmiah dengan berbagai langkah yang harus ditempuh.

Sarana berfikir ilmiah pada dasarnya ada tiga, yaitu: bahasa ilmiah, logika dan matematika, logika dan statistika. Bahasa ilmiah berfungsi sebagai alat komunikasi untuk menyampaikan jalan fikiran seluruh proses berfikir ilmiah. Logika dan matematika mempunyai peranan penting dalam berfikir deduktif sehingga mudah diikuti dan mudah dilacak kembali kebenarannya. Sedang logika dan statistika mempunyai peranan penting dalam berfikir induktif dan mencari konsep-konsep yang berlaku umum. 
Setiap siswa akan berbeda dalam cara mempresentasikan dirinya, beberapa siswa lebih menyadari tentang kesan publiknya dan beberapa siswa lainnya mungkin lebih menggunakan presentasi diri yang strategic sementara siswa yang lain lebih menyukai pembenaran diri (verifikasi diri). Self monitoring merupakan kecenderungan untuk mengubah perilaku dalam merespon terhadap presentasi diri yang dipusatkan pada situasi (Brehm \& Kassin (1993). Selanjutnya menurut Worchel (2000) mengemukakan bahwa self monitoring merupakan penyesuaian perilaku terhadap normanorma situasional dan harapan-harapan dari orang lain. Sedangkan Brigham (1991) menyatakan self monitoring merupakan proses dimana individu mengadakan pemantauan (memonitor) terhadap pengelolaan kesan yang dilakukannya. Individu yang memiliki self monitoring yang tinggi (high self monitors) menitikberatkan pada apa yang layak secara sosial dan menaruh perhatian pada bagaimana siswa berperilaku dalam setting sosial. Siswa menggunakan informasi ini sebagai pedoman tingkah lakunya. Perilaku siswa lebih ditentukan oleh kecocokan dengan situasi daripada sikap dan perasaan siswa yang sebenarnya. Siswa cakap dalam merasakan keinginan dan harapan orang lain, terampil dalam mempresentasikan beberapa perilaku dalam situasi yang berbeda dan dapat merubah cara-cara presentasi diri atau memodifikasi perilaku-perilaku untuk menyesuaikan dengan harapan orang lain.

Menurut Ratih (2010) yang mengemukakan hasil penelitiannya bahwa persentase perubahan perilaku off task yang dimunculkan oleh ketiga subyek penelitian selama diberi treatment, semuanya mengalami penurunan $50 \%$ sampai $83,1 \%$. Persentase perubahan tersebut mengandung pengertian bahwa teknik selfmonitoring dan self reinforcement efektif untuk mengurangi perilaku off task siswa, sedangkan Ayu (2010) mengungkapkan hasil pengembangan yang menunjukkan bahwa tingkat kelayakan/kesesuaian multimedia interaktif dengan topik keterampilan komunikasi menurut ahli media adalah sesuai $(2,78 \%)$, menurut ahli materi adalah sesuai $(2,78 \%)$ dan hasil uji audiens/kelompok kecil tingkat kevalidannya adalah sangat sesuai (3,33\%). Secara keseluruhan media layanan tersebut dapat digunkan dalam pemberian materi di dalam kelas. Saran yang diberikan dalam hal ini adalah 1) media ini hendaknya digunakan oleh guru Bimbingan Konseling dalam pemberian layanan informasi keterampilan komunikasi, 2) terhadap peneliti selanjutnya agar multimedia ini diteliti lebih lanjut hasil pengembanganya dengan melakukan penelitian eksperimen ataupun penelitian tindakan (action research) dalam bimbingan.

\section{SIMPULAN}

1. Kemampuan berpikir ilmiah siswa yang mengikuti pembelajaran dengan pembelajaran kooperatif dalam mata pelajaran biologi di Sekolah Menengah Atas meningkat yang ditunjukkan dengan perbedaan yang signifikan rata-rata hasil belajar siswa sebelum treatment dengan setelah berpikir ilmiah dan treatment.

2. Perbedaan kemampuan berpikir ilmiah antara siswa yang memiliki self monitoring tinggi dan siswa yang memiliki self monitoring rendah dalam mata pelajaran biologi di Sekolah Menengah Atas, didapatkan bahwa pada kelompok self monitoring rendah, rata-rata hasil belajar siswa sebelum treatment adalah sebesar 58,55. Setelah berpikir ilmiah dan treatment, terjadi peningkatan rata-rata hasil belajar sebesar 72,91 dan 84,18 . Demikian juga pada kelompok self monitoring tinggi, rata-rata hasil belajar siswa sebelum treatment adalah sebesar 58,33 . Setelah berpikir ilmiah dan treatment, terjadi peningkatan rata-rata hasil belajar sebesar 71,17 dan 81,33 . 
3. Perbedaan kemampuan berpikir ilmiah siswa yang memiliki self monitoring tinggi yang mengikuti pembelajaran dengan pembelajaran kooperatif learning siswa dalam mata pelajaran biologi di Sekolah Menengah Atas ditunjukkan dengan perbedaan yang signifikan rata-rata hasil belajar siswa antara kelompok self monitoring rendah dengan self monitoring tinggi pada pembelajaran kooperatif learning.

4. Perbedaan kemampuan berpikir ilmiah siswa yang memiliki self monitoring rendah yang mengikuti pembelajaran kooperatif siswa dalam mata pelajaran biologi di Sekolah Menengah Atas ditunjukkan dengan berpikir ilmiah dan tretment memberikan pengaruh yang relatif sama pada kedua kelompok tersebut, tidak terdapat kecenderungan bahwa berpikir ilmiah dan treatment lebih sesuai jika diberikan pada salah satu kelompok self monitoring. Sehingga berpikir ilmiah dan treatment pada kedua kelompok self monitoring mampu meningkatkan hasil belajar siswa dengan efek yang sama.

5. Pengaruh interaksi antara strategi pembelajaran dengan self monitoring terhadap kemampuan berpikir ilmiah dalam mata pelajaran biologi di Sekolah Menengah Atas ditunjukkan dengan berpikir ilmiah, rata-rata nilai hasil belajar siswa kelompok self monitoring rendah adalah sebesar 72,91. Sedangkan rata-rata hasil belajar siswa kelompok self monitoring tinggi sebesar 71,17 . Selisih nilai hasil belajar siswa antara kelompok self monitoring rendah tidak berbeda signifikan dengan self monitoring tinggi setelah berpikir ilmiah.

\section{REFERENSI}

Antonio Zamora. (2000). Melatih siswa terampil berpikir ilmiah.

Brehm, S.S., Kassin., S.M. (1993). Social psycology. USA: Boston: Houghton Mifflin Company.

Brigham, J.C. (1991). Social psychology. New York: Harper Collins Publisher, Inc.

Church E, B, (2006). Scientific Thinking: Step by Step. Diunggah dari web http://gurupembaharu.com/home/melatih-siswa-terampil-berpikir-ilmiah/, http://www2.scholastic.com/browse/article.jsp?id=3747036.

Depdiknas. (2003). Permendiknas No. 22 tahun 2003, Standar Isi.

Mosby's Medical Dictionary, 8th edition. (2009). Elsevier. Diunggah dari web http://medicaldictionary. thefreedictionary.com/Scientific+thinking.

Nita, Veni Dona Ayu. (2010). Pengembangan media pemantauan diri (self monitoring) dan kendali stimulus (stimulus contro/) untuk meningkatkan keterampilan komunikasi. Skripsi, Jurusan Bimbingan Konseling dan Psikologi Program studi Bimbingan dan Konseling FIP Universitas Negeri Malang.

Ratih Eka. (2010). Keefektifan teknik selfmonitoring dan self reinforcement untuk mengurangi perilaku off task siswa SMP Negeri 20 Malang. Skripsi, Program Studi Bimbingan dan Konseling Jurusan Bimbingan Konseling dan Psikologi Fakultas IImu Pendidikan Universitas Negeri Malang.

Slavin R. E. (1994). Educational psychology : Theory and practice. Boston: Johns Hopkins University.

Worchel Wager Water, Gagne, Robert M, Leslie J. Briggs. (2000). Principles of instructional design foth worth. Texas: Harcourt Brace Jovanovich Collage Publisher, 1992. 